\title{
Features of Seasonal Sea Level Oscillations in the Russian Arctic Seas
}

\author{
I. P. Medvedev ${ }^{a, b}$, * \\ a Shirshov Institute of Oceanology, Russian Academy of Sciences, Moscow, 117218 Russia \\ ${ }^{b}$ Fedorov Institute of Applied Geophysics, Moscow, 129128 Russia \\ *e-mail:patamates@gmail.com \\ Received July 10, 2020; revised March 29, 2021; accepted April 8, 2021
}

\begin{abstract}
Based on the analysis of long series of monthly mean sea level values from the database of the PSMSL and ESIMO portals, we obtained estimates of the mean and extreme amplitudes of seasonal oscillations. The mean amplitude of annual sea level oscillations in the White Sea is $7 \mathrm{~cm}$, in the Barents Sea is 9$10 \mathrm{~cm}$, in the Kara Sea, is $8-9 \mathrm{~cm}$, in the Laptev Sea, is $10-11 \mathrm{~cm}$, in the East Siberian and Chukchi seas is $13-14 \mathrm{~cm}$. In the estuarine areas of seas, the amplitude of annual oscillations increases, and the semiannual, third-annual, and quarter-annual components appear in the sea level spectra. They are formed due to the asymmetry of the seasonal sea level variation with a sharp maximum during the flood period in June. Interannual changes in the amplitude of seasonal oscillations were identified and estimates of their extreme values were obtained. In some years, the amplitude of seasonal oscillations reaches $50 \mathrm{~cm}$ in the Yenisei Gulf and Gulf of $\mathrm{Ob}, 60 \mathrm{~cm}$ near the mouth of the Lena River, and $75 \mathrm{~cm}$ at the mouth of the Olenek River.
\end{abstract}

Keywords: sea level, Arctic, flood, seasonal variability, X-12-ARIMA, cluster analysis, spectral analysis

DOI: $10.1134 / \mathrm{S} 0001437021060096$

\section{INTRODUCTION}

Sea level is one of the most pronounced indicators reflecting the state of and changes in the World Ocean. Sea level oscillations can be thought of as the superposition of three components: periodic, random, and trend. The trend component includes positive/negative trends in long-term changes in mean sea level. These trends on the Russian Arctic sea coast are mainly influenced by two factors: (1) an increase in the mean sea level of the World Ocean caused by global climate changes and (2) local vertical movements of the Earth's crust caused by isostatic equilibrium of the Earth's crust after melting of ice sheets. The rate of mean sea level rise according to coastal and satellite observations from 1993 to 2009 was $3.2 \mathrm{~mm} /$ year [8], and according to observational data from 2005 to 2015 , it increased to $3.6 \mathrm{~mm} /$ year [13]. Most of the Russian Arctic coast is characterized by a relatively stable position of the crust [1]. Vertical movements of the crust cause a relative decrease in sea level up to $-1.9 \mathrm{~mm} / \mathrm{year}$ at coastal stations in the Barents Sea and an increase in sea level by $0.07 \mathrm{~mm} /$ year at stations in the Chukchi Sea $[16,19]$. Taking into account the glacial isostatic adjustment (GIA), the rate of mean sea level rise in the Arctic was $2.5 \mathrm{~mm} /$ year, according to data from 1954 to 2006 [20].

Tides make the main contribution to the periodic component of sea level variability. They manifest themselves mainly as regular diurnal and semidiurnal oscillations. The random (stochastic) component of sea level oscillations forms under the influence of atmospheric impact (changes in the surface wind and atmospheric pressure fields) and hydrometeorological factors (ice conditions, river runoff, etc.).

Seasonal oscillations are a periodically correlated random process, since they possess stochasticity and quasiperiodic recurring values. These oscillations form under the influence of various factors, the main of which are changes in seawater density, atmospheric pressure, wind speed and direction, river runoff volume, evaporation, and precipitation [12]. The influence of these factors on sea level oscillations results in temporal and spatial inhomogeneities. In [22], the amplitudes and phases of the annual and semiannual components were calculated from an analysis of long-term series of mean monthly sea level values in the entire World Ocean. In [23], estimates of annual sea level oscillations were obtained from an analysis of 345 coastal and island stations and satellite altimetry data.

The magnitude (range) of seasonal sea level oscillations on islands of the Arctic seas is $13-17 \mathrm{~cm}$; on the mainland coast, up to $20-30 \mathrm{~cm}$; and in the Chukchi Sea, up to $40 \mathrm{~cm} \mathrm{[5].} \mathrm{The} \mathrm{maximum} \mathrm{amplitudes} \mathrm{were}$ found in river mouth zones [15]. The minimum sea level values are observed mainly in April, and the max- 


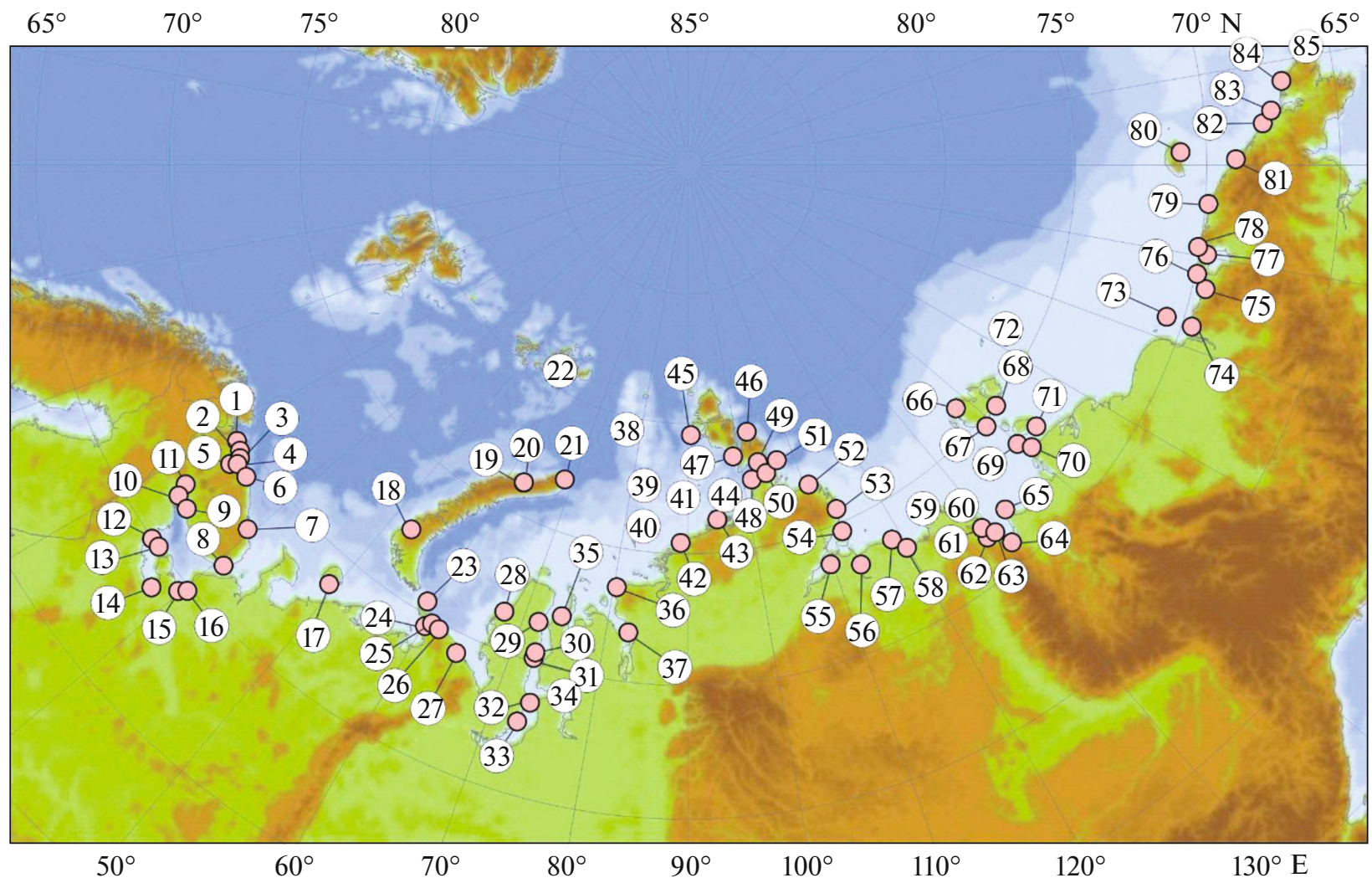

Fig. 1. Sketch map of tide gauge stations (numbers correspond to numbers in Table 1).

imum, in October and December in the Kara Sea; in July and October, in the Laptev and East Siberian seas; and in October-November, in the Chukchi Sea $[5,14]$. At stations in estuarine areas, the maximum sea level values are observed during the June flood period. The most intense rise in sea level is observed in May [15]. The magnitude of seasonal sea level oscillations varies significantly interannually, reaching $50 \mathrm{~cm}$ $[3,4]$. In [2], seasonal sea level oscillations at individual coastal stations in the Arctic were considered, the amplitudes and phases of the annual and semiannual components were calculated, and spectral differences were shown. In [24], the amplitudes and phases of seasonal oscillations were calculated from satellite altimetry data and it was shown that in shallow areas of the Barents and Kara seas, due to seasonal changes in the ice cover and the presence of high-frequency noise, agreement between the altimetry data and coastal observations decreases.

Analysis of the literature has shown that seasonal sea level oscillations in the Russian Arctic seas can reach a value of several decimeters, thereby being the most important factor in the water dynamics in the coastal regions of the seas. This study analyzed long-term series of monthly mean sea level values to estimate the longterm and extreme amplitudes of seasonal oscillations and investigate their spatial and spectral features. A number of interesting new results were obtained.

\section{MATERIALS AND METHODS}

To study the features of seasonal sea level oscillations in the Arctic seas, we used long-term series of sea level observations at stations in different geographic and hydrometeorological conditions: on the open sea coast, in the mouth zones of large rivers, in straits, on islands, and in bays of different size (Fig. 1). These series were formed from monthly mean sea level data acquired from the portals PSMSL (Permanent Mean Sea Level Service, Liverpool, UK) and ESIMO (Unified State Information System on the World Ocean Situation, Obninsk, Russia). A total of 85 stations were selected with a duration of observations greater than 8 years and with a gap/outlier percentage no higher than $12 \%$. The mean observation period for 85 stations was more than 42 years, and the mean percentage of gaps did not exceed 2\%. The stations are located in waters of all Arctic seas washing the coast of the Russian Federation. Detailed information on the data used is presented in Table 1.

To calculate the mean amplitudes of the annual $(\mathrm{Sa})$ and semiannual $(S \mathrm{sa})$ components, classical harmonic analysis with the least squares method was used [21]. Spectral analysis using fast Fourier transform and spectral averaging over segments (Welch method) was used to describe the energy distribution of sea level variations in terms of the oscillation frequency. To increase the number of degrees of freedom and narrow 
Table 1. Characteristics of seasonal oscillations in the sea level in the Arctic seas according to the data of tide gauges

\begin{tabular}{|c|c|c|c|c|c|c|c|c|c|c|c|}
\hline No. & Name & Latitude & Latitude & $\begin{array}{l}\text { Observation } \\
\text { period }\end{array}$ & $\%$ & $\begin{array}{l}S \mathrm{Sa} \\
\mathrm{cm}\end{array}$ & $\begin{array}{c}S \mathrm{Sa} \\
\text { month }\end{array}$ & $\begin{array}{c}S \mathrm{sa}, \\
\mathrm{cm}\end{array}$ & \begin{tabular}{|c|}
$S$ sa, \\
month
\end{tabular} & $\begin{array}{c}A_{\text {mean }}, \\
\mathrm{cm}\end{array}$ & $\begin{array}{l}A_{\max }, \\
\mathrm{cm}\end{array}$ \\
\hline 1 & Pechenga (Liinakhamari) & 31.37 & 69.65 & $1958-1990$ & 98.0 & 9.5 & 11 & 1.3 & 1 & 12 & 14 \\
\hline 2 & Cape Pikshuev & 32.43 & 69.55 & $1955-1990$ & 88.4 & 8.9 & 11 & 1.1 & 1 & 12 & 14 \\
\hline 3 & Kislogubskaya ТPP & 33.10 & 69.40 & $1970-1990$ & 95.1 & 12.2 & 11 & 0.3 & 1 & 14 & 20 \\
\hline 4 & Polyarnoye & 33.48 & 69.20 & 1936-2018 & 99.9 & 9.7 & 11 & 1.5 & 6 & 13 & 16 \\
\hline 5 & Murmansk & 33.05 & 68.97 & $1952-2018$ & 97.8 & 9.4 & 11 & 2.0 & 6 & 12 & 14 \\
\hline 6 & Teriberka & 35.12 & 69.20 & 1949-1990 & 98.6 & 10.5 & 11 & 1.9 & 6 & 13 & 15 \\
\hline 7 & Yokanga & 39.50 & 68.05 & $1953-1990$ & 93.1 & 10.3 & 11 & 1.4 & 6 & 12 & 15 \\
\hline 8 & Sosnowiec Island & 40.68 & 66.48 & 1985-2018 & 95.8 & 7.4 & 10 & 1.7 & 5 & 12 & 14 \\
\hline 9 & Umba & 34.35 & 66.68 & 1985-2018 & 99.8 & 7.0 & 10 & 1.9 & 6 & 10 & 13 \\
\hline 10 & Kovda & 32.88 & 66.70 & 1985-1993 & 100.0 & 8.1 & 10 & 4.1 & 1 & 13 & 14 \\
\hline 11 & Kandalaksha & 32.35 & 67.15 & $1985-2018$ & 99.3 & 5.0 & 9 & 1.5 & 1 & 8 & 10 \\
\hline 12 & Kem-port & 34.80 & 64.98 & $1985-2018$ & 98.0 & 6.8 & 10 & 1.3 & 6 & 10 & 15 \\
\hline 13 & Solovki & 35.70 & 65.02 & $1985-2018$ & 98.3 & 6.8 & 10 & 1.3 & 6 & 10 & 16 \\
\hline 14 & Onega & 38.12 & 63.90 & $1985-2004$ & 99.2 & 3.4 & 4 & 10.6 & 5 & 22 & 28 \\
\hline 15 & Severodvinsk & 39.78 & 64.58 & $1985-2018$ & 99.5 & 10.8 & 11 & 1.9 & 1 & 14 & 20 \\
\hline 16 & Mudyug Island & 40.28 & 64.85 & 1985-2018 & 100.0 & 3.7 & 10 & 2.6 & 5 & 10 & 13 \\
\hline 17 & Bugrino & 49.33 & 68.80 & 1962-2018 & 94.3 & 8.3 & 11 & 2.5 & 5 & 11 & 16 \\
\hline 18 & Malye Karmakuly & 52.70 & 72.37 & $1950-2018$ & 93.4 & 5.1 & 11 & 0.6 & 6 & 10 & 14 \\
\hline 19 & Russkaya Gavan 2 & 62.58 & 76.18 & $1953-1993$ & 97.3 & 11.2 & 11 & 2.7 & 1 & 14 & 18 \\
\hline 20 & Russkaya Gavan & 62.58 & 76.20 & $1953-1991$ & 98.9 & 11.3 & 11 & 2.4 & 1 & 14 & 18 \\
\hline 21 & Cape Zhelaniya (bay) & 68.55 & 76.95 & $1951-1996$ & 99.6 & 7.8 & 10 & 2.7 & 1 & 10 & 13 \\
\hline 22 & Krenkel HMO & 58.05 & 80.62 & $1962-1999$ & 96.5 & 5.5 & 10 & 2.3 & 1 & 8 & 10 \\
\hline 23 & $\begin{array}{l}\text { Fedorov HMO } \\
\text { (Cape Bolvansky Nos) }\end{array}$ & $59 / 08$ & 70.45 & $1951-1993$ & 100.0 & 6.2 & 8 & 7.0 & 6 & 21 & 27 \\
\hline 24 & Cape Bely Nos & 60.22 & 69.60 & $1957-1992$ & 94.7 & 15.8 & 10 & 2.5 & 6 & 20 & 25 \\
\hline 25 & Yugorsky Strait & 60.75 & 69.82 & $1950-1994$ & 97.0 & 14.1 & 10 & 2.4 & 6 & 19 & 25 \\
\hline 26 & Amderma & 61.70 & 69.75 & $1950-2018$ & 99.9 & 12.1 & 10 & 2.3 & 6 & 15 & 17 \\
\hline 27 & Ust-Kara & 64.52 & 69.25 & $1950-2018$ & 99.8 & 8.0 & 10 & 4.9 & 6 & 17 & 26 \\
\hline 28 & Morzhovaya & 67.58 & 71.42 & 1954-1994 & 100.0 & 11.2 & 10 & 3.9 & 6 & 17 & 19 \\
\hline 29 & Tambey & 71.83 & 71.50 & $1982-1994$ & 99.3 & 5.5 & 10 & 7.1 & 1 & 13 & 14 \\
\hline 30 & Tadebya-Yaha & 72.57 & 70.37 & $1955-1994$ & 99.0 & 5.9 & 8 & 7.3 & 6 & 22 & 26 \\
\hline 31 & Seyakha & 72.57 & 70.15 & 1967-1994 & 97.6 & 7.4 & 7 & 8.0 & 6 & 21 & 24 \\
\hline 32 & Cape Kamenny & 73.58 & 68.50 & 1982-1994 & 100.0 & 1.7 & 6 & 9.9 & 6 & 21 & 27 \\
\hline 33 & Novy Port & 72.88 & 67.68 & $1982-2018$ & 93.2 & 9.0 & 6 & 4.3 & 1 & 16 & 24 \\
\hline 34 & Antipayuta & 76.85 & 69.08 & $1965-1988$ & 100.0 & 17.5 & 7 & 17.8 & 6 & 45 & 49 \\
\hline 35 & 60 let VLKSM & 74.33 & 71.97 & $1982-1992$ & 100.0 & 4.4 & 9 & 6.1 & 6 & 11 & 13 \\
\hline 36 & Dikson Island (bay) & 80.40 & 73.50 & $1950-1997$ & 98.8 & 6.7 & 9 & 5.7 & 6 & 13 & 17 \\
\hline 37 & Sopochnaya Karga & 82.70 & 71.87 & 1958-2018 & 98.8 & 11.3 & 7 & 13.0 & 6 & 35 & 50 \\
\hline 38 & Vize Island & 76.98 & 79.50 & $1953-2012$ & 98.5 & 8.0 & 10 & 3.6 & 1 & 10 & 13 \\
\hline 39 & Uedineniya Island & 82.20 & 77.50 & $1953-1995$ & 99.4 & 7.4 & 10 & 3.8 & 1 & 10 & 14 \\
\hline 40 & Izvestiy TsIK Islands & 82.95 & 75.95 & 1954-2018 & 100.0 & 9.2 & 10 & 3.1 & 1 & 12 & 15 \\
\hline 41 & Isachenko Island & 89.20 & 77.15 & 1954-1994 & 99.8 & 5.8 & 10 & 3.7 & 1 & 10 & 12 \\
\hline 42 & Cape Sterlegova & 88.90 & 75.42 & $1950-1995$ & 100.0 & 8.2 & 10 & 4.7 & 1 & 13 & 16 \\
\hline 43 & Pravda Island & 94.77 & 76.27 & $1950-1994$ & 99.8 & 7.5 & 10 & 3.2 & 6 & 12 & 18 \\
\hline
\end{tabular}


Table 1. (Contd.)

\begin{tabular}{|c|c|c|c|c|c|c|c|c|c|c|c|}
\hline No. & Name & Latitude & Latitude & $\begin{array}{c}\text { Observation } \\
\text { period }\end{array}$ & $\%$ & $\begin{array}{l}\mathrm{Sa}, \\
\mathrm{cm}\end{array}$ & $\begin{array}{c}\text { Sa, } \\
\text { month }\end{array}$ & $\begin{array}{c}\text { Ssa, } \\
\mathrm{cm}\end{array}$ & \begin{tabular}{|c|} 
Ssa, \\
month
\end{tabular} & \begin{tabular}{|c|}
$A_{\text {mean }}$ \\
$\mathrm{cm}$
\end{tabular} & $\begin{array}{c}A_{\max }, \\
\mathrm{cm}\end{array}$ \\
\hline 44 & Russky Island & 96.43 & 77.17 & $1951-1985$ & 100.0 & 5.6 & 10 & 3.6 & 6 & 8 & 12 \\
\hline 45 & Cape Golomyanny & 90.62 & 79.55 & 1954-2009 & 99.1 & 4.6 & 10 & 3.3 & 1 & 8 & 13 \\
\hline 46 & Cape Peschany & 102.48 & 79.43 & $1962-1994$ & 97.4 & 4.0 & 9 & 3.8 & 1 & 8 & 10 \\
\hline 47 & Krasnoflotskie Islands & 98.83 & 78.60 & $1954-1987$ & 100.0 & 4.1 & 9 & 3.4 & 1 & 8 & 11 \\
\hline 48 & Heiberg Islands & 101.52 & 77.60 & $1951-1995$ & 100.0 & 5.2 & 10 & 3.3 & 1 & 9 & 12 \\
\hline 49 & Solnechnaya Bay & 103.27 & 78.20 & $1951-1991$ & 100.0 & 5.7 & 9 & 3.0 & 1 & 9 & 11 \\
\hline 50 & $\begin{array}{l}\text { Cape Chelyuskin } \\
\text { (Fedorov HMO) }\end{array}$ & 104.30 & 77.72 & $1950-2018$ & 88.3 & 3.9 & 10 & 2.2 & 6 & 7 & 15 \\
\hline 51 & Maly Taimyr Island & 106.82 & 78.08 & $1950-1994$ & 98.3 & 4.8 & 9 & 2.8 & 6 & 7 & 12 \\
\hline 52 & Andrey Island & 110.75 & 76.80 & $1951-1999$ & 99.7 & 8.0 & 9 & 3.3 & 1 & 12 & 14 \\
\hline 53 & Maria Pronchishcheva Bay & 113.43 & 75.53 & $1951-1970$ & 100.0 & 8.6 & 9 & 3.7 & 6 & 11 & 14 \\
\hline 54 & Preobrezheniya Island & 112.93 & 74.67 & $1951-1995$ & 98.3 & 10.1 & 9 & 3.4 & 1 & 12 & 17 \\
\hline 55 & Cape Kosisty & 109.73 & 73.65 & 1954-1990 & 100.0 & 10.4 & 9 & 6.2 & 1 & 17 & 20 \\
\hline 56 & Anabar & 113.50 & 73.22 & 1989-2018 & 100.0 & 17.6 & 8 & 7.6 & 6 & 33 & 43 \\
\hline 57 & Cape Terpyay Tumsa & 118.67 & 73.55 & 1956-1998 & 97.8 & 10.2 & 9 & 3.0 & 1 & 13 & 17 \\
\hline 58 & Ust Olenek & 119.87 & 73.00 & $1950-1980$ & 100.0 & 25.5 & 7 & 21.7 & 6 & 68 & 75 \\
\hline 59 & Dunay Island & 124.50 & 73.93 & $1951-2011$ & 99.2 & 9.8 & 9 & 1.6 & 1 & 14 & 21 \\
\hline 60 & Sagyllah-Ary & 128.88 & 73.15 & $1962-1980$ & 100.0 & 22.6 & 6 & 19.3 & 6 & 56 & 60 \\
\hline 61 & Cape Bykov & 129.12 & 72.00 & 1975-1999 & 88.7 & 14.4 & 7 & 10.8 & 6 & 36 & 39 \\
\hline 62 & Tiksi Bay & 128.92 & 71.58 & 1949-2010 & 100.0 & 12.6 & 8 & 5.6 & 1 & 16 & 20 \\
\hline 63 & Muostakh Island & 130.03 & 71.55 & $1951-1995$ & 100.0 & 11.1 & 8 & 5.8 & 1 & 16 & 18 \\
\hline 64 & Naiba & 130.75 & 70.85 & 1979-1996 & 98.0 & 9.8 & 8 & 4.6 & 1 & 15 & 18 \\
\hline 65 & Buor-Khaya & 132.77 & 71.95 & 1954-1993 & 95.1 & 9.2 & 8 & 4.1 & 1 & 14 & 20 \\
\hline 66 & Kotelny Island & 137.87 & 76.00 & $1951-2018$ & 99.9 & 11.0 & 9 & 2.4 & 1 & 14 & 18 \\
\hline 67 & Sannikov Strait & 138.90 & 74.67 & $1950-2018$ & 98.3 & 10.2 & 9 & 3.2 & 1 & 13 & 17 \\
\hline 68 & Bunge land & 142.12 & 74.88 & $1951-1987$ & 100.0 & 11.2 & 9 & 4.1 & 1 & 13 & 15 \\
\hline 69 & Cape Kigilyakh & 139.87 & 73.33 & $1951-2018$ & 99.9 & 9.9 & 9 & 2.4 & 1 & 13 & 16 \\
\hline 70 & Cape Svyatoi Nos & $140 / 73$ & 72.83 & $1951-1987$ & 100.0 & 7.8 & 8 & 3.8 & 6 & 12 & 14 \\
\hline 71 & Cape Shalaurov & 143.23 & 73.18 & $1950-2001$ & 98.5 & 11.3 & 9 & 3.0 & 1 & 14 & 17 \\
\hline 72 & Zhokhov Island & 152.83 & 76.15 & $1959-1993$ & 100.0 & 9.8 & 9 & 4.4 & 1 & 14 & 15 \\
\hline 73 & Chetyrekhstolbovoi Island & 162.48 & 70.63 & $1951-1994$ & 100.0 & 13.2 & 9 & 4.4 & 1 & 17 & 19 \\
\hline 74 & Ambarchik Bay & 162.30 & 69.62 & $1950-1995$ & 100.0 & 12.5 & 8 & 7.6 & 1 & 21 & 24 \\
\hline 75 & Rau-Chua & 166.58 & 69.50 & $1950-2002$ & 91.2 & 12.1 & 9 & 4.1 & 1 & 15 & 19 \\
\hline 76 & Ayon Island & 167.98 & 69.93 & $1954-2002$ & 99.1 & 12.5 & 9 & 4.6 & 1 & 17 & 20 \\
\hline 77 & Pevek & 170.25 & 69.70 & $1950-2015$ & 96.7 & 14.0 & 9 & 4.0 & 1 & 17 & 24 \\
\hline 78 & Valkarkay & 170.93 & 70.08 & $1956-1993$ & 97.3 & 12.2 & 9 & 3.9 & 1 & 16 & 19 \\
\hline 79 & Cape Billings & 175.77 & 69.88 & $1953-1995$ & 99.2 & 13.8 & 9 & 3.6 & 1 & 17 & 20 \\
\hline 80 & Wrangel Island & -178.48 & 70.98 & $1950-2000$ & 99.0 & 12.9 & 9 & 3.2 & 1 & 14 & 17 \\
\hline 81 & Cape Schmidt & -179.37 & 68.90 & $1950-1994$ & 100.0 & 14.2 & 9 & 2.4 & 1 & 17 & 21 \\
\hline 82 & Cape Vankarem & -175.83 & 67.83 & $1950-2002$ & 98.4 & 13.6 & 9 & 1.5 & 2 & 17 & 22 \\
\hline 83 & Kolyuchin Island & -174.65 & 67.48 & $1950-1991$ & 100.0 & 13.9 & 9 & 0.2 & 3 & 17 & 23 \\
\hline 84 & Cape Netten & -171.93 & 66.97 & $1950-1995$ & 98.7 & 16.5 & 9 & 1.0 & 2 & 20 & 26 \\
\hline 85 & Ratmanov Island & -169.13 & 65.85 & $1950-1986$ & 100.0 & 9.2 & 9 & 1.6 & 5 & 12 & 16 \\
\hline
\end{tabular}


the confidence intervals when calculating the spectrum, a Kaiser-Bessel spectral window with half-window overlaps was used.

Seasonal sea level oscillations are a periodically correlated random process, as a result of which classical spectral and harmonic analysis methods yield only averaged characteristics. To identify the extreme characteristics of seasonal oscillations and their interannual variability requires methods that take into account the nonstationarity of the process. In this study, the X-12-ARIMA seasonal correction procedure was used to isolate seasonal sea level oscillations in the Arctic seas. [11]. This method is widely used when analyzing the seasonal variability of various economic indicators. Recent decades have seen studies that have successfully applied this method to analyze the seasonal variability of the surface temperature of the World Ocean [17] and sea level oscillations [6, 10]. The obtained series of seasonal sea level oscillations made it possible to study their interannual variability and estimate the mean and maximum amplitudes during the 20th-21st centuries.

\section{HARMONIC ANALYSIS}

In harmonic analysis, the seasonal sea level components are considered as a deterministic process; in this case, sea level variability can be represented as

$$
\begin{gathered}
\eta(t)=H_{0}+A_{S \mathrm{a}} \cos \left(\omega_{0} t-P_{S \mathrm{a}}\right) \\
+A_{S \mathrm{sa}} \cos \left(2 \omega_{0} t-P_{S \mathrm{Sa}}\right),
\end{gathered}
$$

where $\eta$ is the sea level value, $H_{0}$ is the mean sea level, $A_{S a}, A_{S \mathrm{sa}}, P_{S \mathrm{a}}, P_{S \mathrm{sa}}$ are the harmonic amplitudes and phases $S$ a and $S$ sa respectively; $\omega_{0}=2 \pi / 12$ is the annual frequency; $t$ is the time, months. This approach makes it possible to obtain mean estimates for the amplitudes and phases of annual and semiannual sea level oscillations.

The harmonic constants were calculated for all 85 stations. Among the various components of longterm sea level oscillations, the annual ones $(\mathrm{Sa})$ reach the highest values. The spatial distribution of $S \mathrm{a}$ has a global pattern and local features. The global pattern is an increase in the amplitudes of annual oscillations from west to east (Fig. 2, Table 1). The mean amplitude of annual sea level oscillations in the White Sea is $7 \mathrm{~cm}$; in the Barents Sea, 9-10 cm; in the Kara Sea, $8-9 \mathrm{~cm}$; in the Laptev Sea, $10-11 \mathrm{~cm}$; in the East Siberian and Chukchi seas, $13-14 \mathrm{~cm}$. Local features are manifested near river mouths, as well as in straits. At stations near the Kara Gates, Shokalsky, and Vilkitsky straits, the amplitude of annual oscillations does not exceed 4-6 cm. In the Yugorsky Strait, the $S a$ amplitude increases to $12-16 \mathrm{~cm}$. Abnormally high amplitudes of annual oscillations are observed at river mouths: up to $11 \mathrm{~cm}$ in the Yenisei Gulf, and up to 23 and $25 \mathrm{~cm}$ near the mouths of the Lena and Olenek rivers, respectively. In the Gulf of $\mathrm{Ob}$, the $\mathrm{Sa}$ ampli- tude varies greatly: from $2 \mathrm{~cm}$ at Cape Kamenny station to $18 \mathrm{~cm}$ at Antipayuta station in Taz Estuary.

At the mouths of large rivers and bays, there is an increase in the amplitudes of the six-month $S$ sa component. The $S \mathrm{sa}$ amplitude is $11 \mathrm{~cm}$ at the mouth of the Onega River; from 4 to $18 \mathrm{~cm}$ in the Gulf of $\mathrm{Ob}$ and Taz Estuary; up to $13 \mathrm{~cm}$ in the Yenisei Gulf; up to $22 \mathrm{~cm}$ at the mouth of the Olenek River; up to $19 \mathrm{~cm}$ near the mouth of the Lena River; and $8 \mathrm{~cm}$ near the mouth of the Kolyma River. The mean amplitudes in the Russian Arctic seas are 2-4 cm and less than $2 \mathrm{~cm}$ in the Chukchi Sea.

The phases of annual and semiannual oscillations were also calculated, which were recalculated to months. The maximum of the annual component in waters of the Chukchi, East Siberian, and Laptev seas is observed mainly in September; in the Kara and White seas, in October; and in the Barents Sea, in November. At river mouths and in bays, the peak annual component is reached approximately $1-2$ months earlier: in June-August in the Gulf of $\mathrm{Ob}$ and near the mouth of the Lena; in July, in Yenisei Gulf and at the mouth of the Olenek River.

The peak semiannual harmonic is observed twice a year. In the Barents Sea and in the western part of the Kara Sea in June and December; in the eastern Kara, the Laptev Sea, and the East Siberian seas, in January and July. In the White Sea, the peak is observed in May-June and November-December; in the Chukchi Sea, in February-March and August-September.

The calculated amplitudes of the seasonal components are several times higher than the astronomical amplitudes of these harmonics, which correspond to the static theory of long-period tides. It is possible to estimate the amplitudes of the annual $(\mathrm{Sa})$ and semiannual ( $S$ sa) astronomical tidal components (in $\mathrm{mm}$ ):

$$
\begin{gathered}
A_{S \mathrm{a}}^{\text {Tide }}=-3.1\left(\frac{3}{2} \sin ^{2} \varphi-\frac{1}{2}\right) \cos \left(h-p^{\prime}\right) K_{E}, \\
A_{S \mathrm{sa}}^{\text {Tide }}=-19.5\left(\frac{3}{2} \sin ^{2} \varphi-\frac{1}{2}\right) \cos (2 h) K_{E},
\end{gathered}
$$

where $\varphi$ is the latitude of the location; $h$ is the mean longitude of the Sun, which increases by $0.0411^{\circ}$ during the mean solar hour, zero at the equinox on March 21, and $\pi / 2$ on June 21; $p$ ' is the longitude of the perigee of the Sun, which changes over the course of 20942 years and for 2000 is $283^{\circ}$; $K_{E}$ is the decreasing tidal coefficient [21]. $K_{E}=(1+k-h)=0.69$, where $k=0.3$ and $h=0.61$ are the Love numbers characterizing the elastic properties and density of matter within the Earth. The maximum amplitudes are observed at the poles, and the minimum (equal to zero), at $35.27^{\circ} \mathrm{N}$ and $\mathrm{S}$.

The amplitude of the astronomical annual component $A_{S \mathrm{a}}^{\text {Tide }}$ at latitudes from $70^{\circ}$ to $80^{\circ}$ varies from 0.17 to $0.20 \mathrm{~cm}$, and the semiannual, from 1.11 to $1.28 \mathrm{~cm}$. The mean amplitudes of the long-term components 

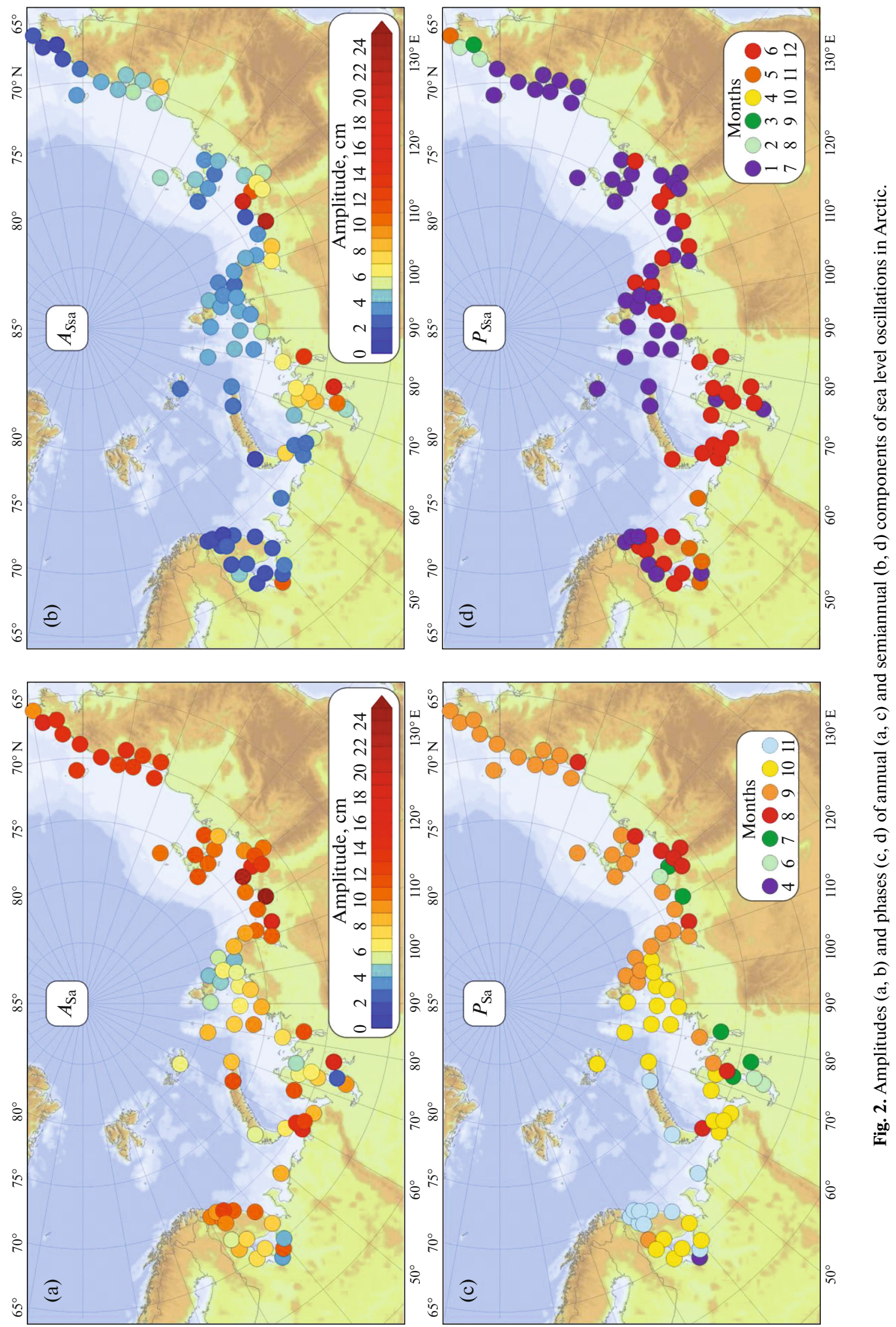
calculated in this study exceed the astronomical ones by three to eight times for $S$ sa and 30-50 times for $S \mathrm{a}$. Thus, $A_{S \mathrm{a}}^{\text {Tide }}$ is about $2-3 \%$ of $A_{S \mathrm{a}}$ in the Arctic seas.

\section{SPECTRAL ANALYSIS}

The spectra were calculated to estimate the frequency distribution of the sea level oscillations in terms of energy. For spectral analysis, coastal stations with long observation series with a small percentage of gaps in the data were selected, located in different geographic and hydrometeorological conditions (Fig. 1, Table 1): on the open sea coast (Murmansk and Dunay Island), in the mouth zones of large (TadebyaYakha in the Gulf of Ob, Sopochnaya Karga in the Yenisei Gulf) and medium-sized rivers (Ust-Kara in the Kara Gulf), in straits (Sannikov Strait and Cape Kigilyakh), on islands (Izvestiy TsIK Islands, Vize Island), and in bays of various size (Amderma at the outlet from Baidarata Bay, Tiksi Bay in Buor-Khaya Bay, and Pevek in Chaun Bay). When calculating spectra, the segment length $N$ for most spectra was 256 months (about 21 years); for Tadebya-Yakha station, 128 months (10.6 years). The number of degrees of freedom varied from 8 to 12 .

The main peak in all spectra corresponds to the annual oscillation $\mathrm{Sa}$ (Fig. 3). For periods less than a year, one can also observe seasonal components with frequencies that are multiples of the year: $S$ sa, thirdannual $S \mathrm{ta}$, and quarter-annual $S \mathrm{qa}$. Third- and quarter-annual sea level oscillations do not exist in reality. These high-frequency components in the spectra are formed due to the asymmetry of annual sea level oscillations. The asymmetry of seasonal oscillations is most pronounced in the estuarine runoff regions of large rivers. For the stations of Tadebya-Yakha (the Gulf of Ob, Fig. 3k) and Sopochnaya Karga (Yenisei Gulf, Fig. 31), the peaks corresponding to seasonal overtones ( $S \mathrm{sa}, S \mathrm{ta}$, and $S \mathrm{qa}$ ) have the same spectral density level as the main seasonal annual peak $S$ a, and that of $S$ sa even exceeds $S \mathrm{a}$. Such a spectral structure is formed due to the asymmetric seasonal variability in sea level with a sharp maximum level during the flood period, which in this region is observed mainly in June. The sea level at these stations exceeds the mean by $30-50 \mathrm{~cm}$, which is five to eight times greater than deviations of sea level in the other months. A similar structure is also observed in the spectrum of level oscillations at Ust-Kara station (Fig. 3k) in Kara Bay. The runoff volume of the Kara River, which flows into the bay of the same name, significantly lags behind the $\mathrm{Ob}$ and Yenisei runoff volume. Despite this, high-frequency overtones of seasonal oscillations are also observed in the spectrum of sea level oscillations at Ust-Kara station, but their energy decreases with increasing frequency. On the sea level oscillations spectrum at Murmansk, located in the Kola Bay, into which the Tuloma and Kola rivers flow, one can also find weakly expressed third- and quarter-annual peaks, the spectral density of which hardly exceeds the level of the continuous spectrum. In the sea level oscillations spectra for stations far from river mouths (e.g., Izvestiy TsIK Islands or Vize Island), no significant peaks with periods of seasonal overtones (third- or quarter-annual) were found. It should be noted that these high-frequency seasonal peaks are also not observed in the sea level oscillations spectra at stations of Dunay and Amderma islands, which are geographically located near river mouths, but in reality experience less river runoff impact on sea level oscillations. Even a semiannual peak is absent in these spectra, and seasonal oscillations are expressed only by a peak with an annual period. Apparently, this is due to the relatively uniform seasonal variability in sea level, the character of which is close to sinusoid.

The semiannual peak $S$ sa is found not only in the spectra of sea level oscillations in estuarine areas, but also in bays and straits. On the sea level oscillations spectrum at the station in Sannikov Strait, in addition to the annual and semiannual peaks, one can find a quarter-annual peak. At the same time, there is no third-annual peak in this spectrum. Perhaps this is due to the asymmetry of the semiannual component of seasonal sea level oscillations due to water exchange through the strait. The spectra in Pevek and Tiksi Bay show clearly pronounced $S$ a and $S$ sa.

\section{SEASONAL VARIABILITY IN SEA LEVEL}

To analyze the seasonal variability, mean longterm sea level values were calculated for each individual month. Preliminarily, a linear trend was excluded from the series under consideration, which is formed under the influence of a global rise in the mean sea level of the World Ocean and local vertical movements of the crust. Figures 4 and 5 show the mean long-term seasonal variability in sea level for different stations. Also, for each month, the standard deviation of monthly sea level anomalies was calculated, which are shown in blue in Figs. 4 and 5.

The stations were preliminarily divided into two groups: open sea coast and estuarine zones. At all the stations under consideration, a similar type of seasonal sea level changes is observed: the lowest sea level is reached in April, followed by continuous sea level rises until autumn-winter. From January to April, the sea level drops. In the open sea parts of water areas (first group of stations), the sea level in the seasonal variability gradually increases/decreases (Fig. 4). In the Barents Sea (e.g., Murmansk in Fig. 4b), sea level increases continuous from April to December, after which it decreases. In the White Sea, the seasonal variability in sea level (Fig. 4a) has a similar character; the sea level rises until October-December, and in November, at all the White Sea stations, a sharp local decrease in the sea level is observed. 

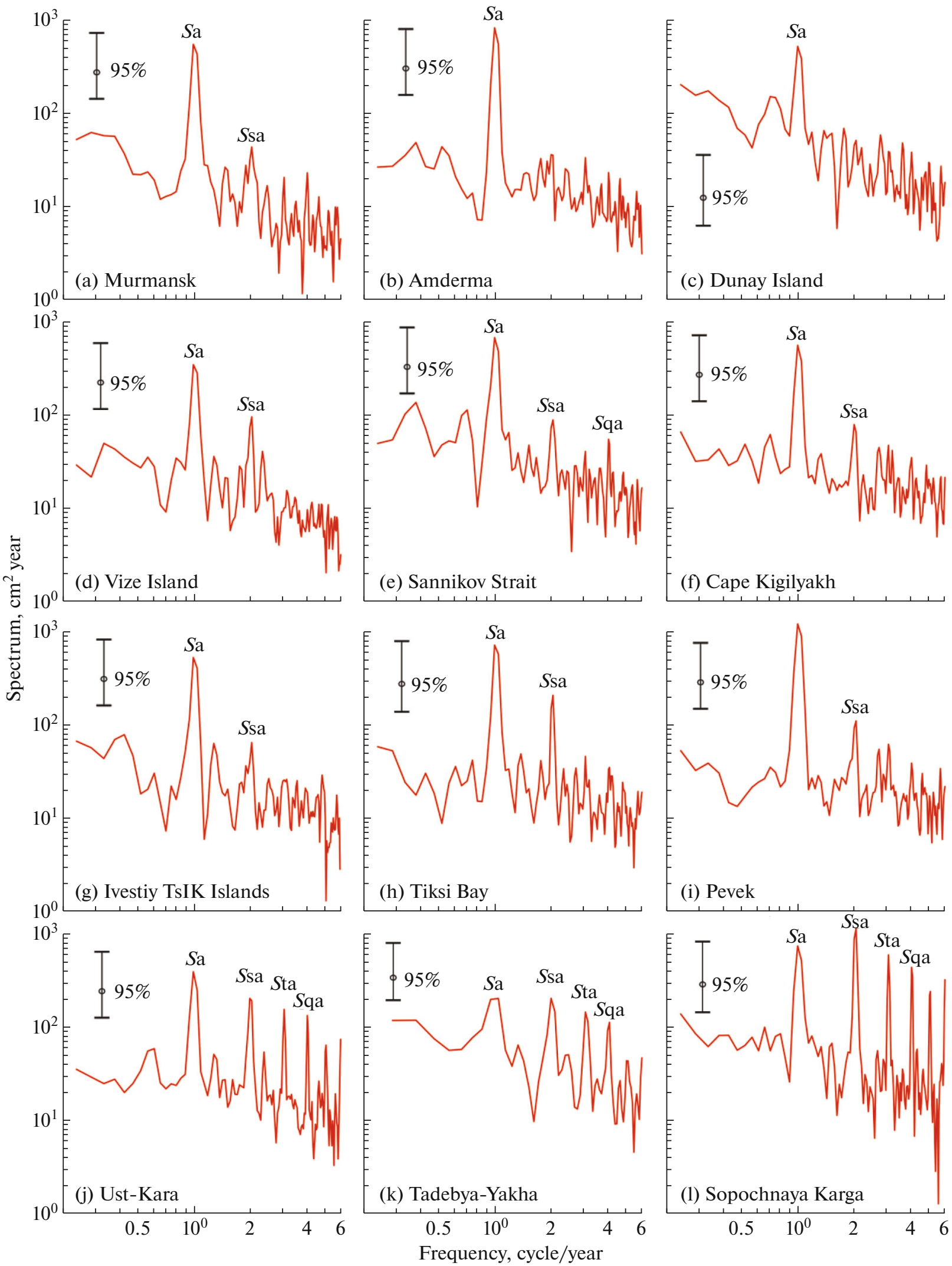

Fig. 3. Spectra of long-term sea level oscillations at various stations. 

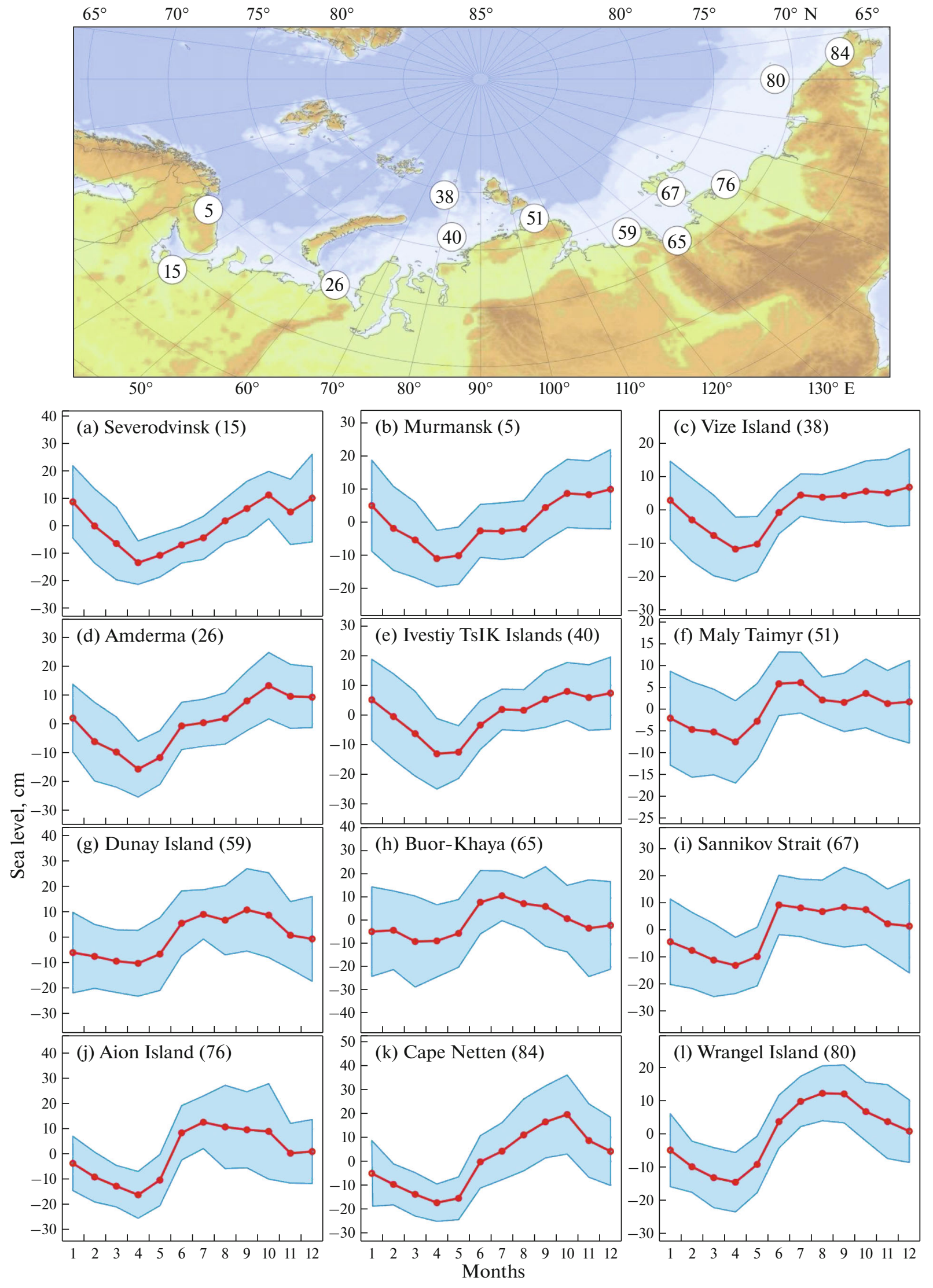

Fig. 4. Mean long-term seasonal variability of mean sea level at stations on the open sea coast, islands, and in straits. 

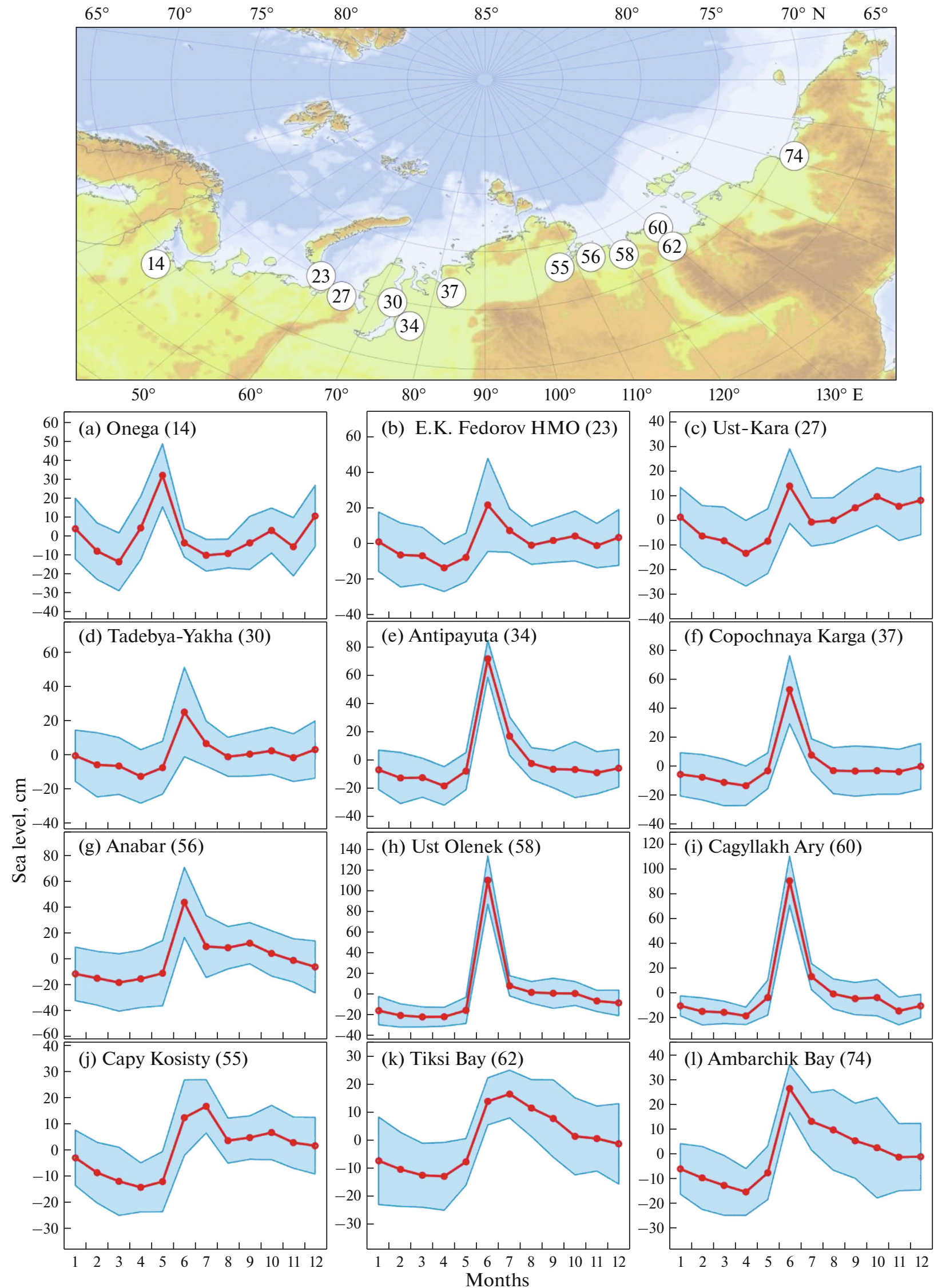

Fig. 5. Mean long-term seasonal variability of mean sea level at stations near estuaries. 
In the Kara Sea (Figs. 4c-4f), a local maximum in June is superimposed on an increase in the sea level from April to October-December, caused by the influence of floods of large Siberian rivers $(\mathrm{Ob}$ and Yenisei). At Maly Taimyr station, east of the Vilkitsky Strait, this maximum is more pronounced than at stations in the Kara Sea. In the Laptev Sea, the maximum sea level is observed from July to September, after which it decreases until April. A similar pattern is also observed in the East Siberian and Chukchi seas, where the seasonal variability curve approaches a regular sinusoid.

Near river mouths, a continuous increase in sea level from April to October is overlapped by a local maximum in June, caused by flooding of Siberian rivers (Fig. 5). At stations inside bays or near the mouths of large rivers, this June maximum increases sharply (e.g., Antipayuta in Taz Estuary, Sopochnaya Karga in Yenisei Gulf, Ust-Olenek in Olenek Bay, and Sagyllakh-Ary at the mouth of the Lena River). Moreover, the higher the station is located, the sharper the peak of the June maximum (see, e.g., Tadebya-Yakha and Antipayuta). At the Kosisty and Tiksi stations, located in Khatanga Bay and near the mouth of the Lena River, respectively, the summer rise in sea level is observed in June-July. This due to the certain distance the stations are located from the place where the rivers flow into the sea. In Onega Bay, the maximum sea level caused by high water is observed in May (Fig. 5a). This is due to the earlier onset of floods in the basins of rivers flowing into the White Sea.

\section{EXTREME SEASONAL OSCILLATIONS}

In this study, the X-12-ARIMA seasonal correction procedure [11] was applied to isolate and subsequently analyze seasonal sea level oscillations. This method makes it possible to split the original time series $X_{t}$ (e.g., sea level changes) into three components: trend $T_{t}$ (in this case, interannual sea level oscillations), seasonal cycle $S_{t}$, and an irregular component $I_{t}$ :

$$
X_{t}=T_{t}+S_{t}+I_{t},
$$

where $t=1,2, \ldots, N$ and $N$ is the length of the series (number of values).

At the first stage of the procedure for calculating the trend component $T$, time series $X$ is smoothed by a 12 -month centered moving average $M A_{2 \times 12}$ :

$$
=\frac{X_{t-6}+2 X_{t-5}+\ldots+2 X_{t}+\ldots+2 X_{t+5}+X_{t+6}}{24} .
$$

Then, the trend component is subtracted from the original time series:

$$
Z_{t}=X_{t}-T_{t},
$$

which yields a time series that is the sum of the seasonal component and short-period noise. This is fol- lowed by subjecting the time series $Z_{t}$ to an $S M A_{2 \times 2}$ filter, which is the seasonal moving average $M A_{2 \times 2}$ :

$$
M A_{2 \times 2}\left(X_{t}\right)=\frac{X_{t-1}+2 X_{t}+X_{t+1}}{4},
$$

which is applied to the time series for each individual month. The resulting (seasonal) time series is corrected by subtracting the moving average $M A_{2 \times 12}$, which represents the mean seasonal cycle.

At the second stage, smoothing with the 12-month centered moving average $M A_{2 \times 12}$ is applied to the time series obtained after subtraction of the seasonal component:

$$
Y_{t}=X_{t}-S_{t}
$$

which makes it possible to improve the estimation of the trend component $T_{t}=M A_{2 \times 12}\left(Y_{t}\right)$. After this, the improved trend component is subtracted from the original time series $Z_{t}=X_{t}-T_{t}$. Then, the time series $Z_{t}$ is again subjected to the seasonal filter $S M A_{2 \times 2}$, making it possible to improve the estimation of the seasonal component $S_{t}$.

The third step is an application of the 12-month centered moving mean to the already corrected time series $Y_{t}$. Then, the residual (irregular) component $I_{t}=X_{t}-T_{t}-S_{t}$ is calculated. Moreover, the seasonal series obtained at the second stage of the procedure remains unchanged. As a result of the above transformations, we obtain individual series corresponding to the trend $T_{t}$, seasonal $S_{t}$, and irregular $I_{t}$ components. A detailed description of the X-12-ARIMA seasonal correction method is presented in the works [9, 11, 17].

Figure 6 shows the result of applying this filtering method for monthly mean sea level values at two Arctic stations: Amderma (a-b) and Sopochnaya Karga (c-d). The gray dashed curve in Fig. 6 shows the initial sea level changes at the stations. Figures $6 \mathrm{a}$ and $6 \mathrm{~b}$ (green curve) show the trend component, representing lowfrequency sea level oscillations. The irregular component (red curve in Figs. 6a and 6c) represents sea level changes with periods predominantly less than a year. These sea level oscillations are formed under the influence of aperiodic short-term changes in the contribution of the water balance components, as well as changes in the atmospheric pressure and wind fields over the surface of the seas. A certain contribution to the formation of individual monthly sea level values can also be made by long-term surges with periods of several days. The filtered seasonal sea level oscillations are shown in Figs. 6b and 6d. Sopochnaya Karga station is located in the Yenisei Gulf, as a result of which the June maximum caused by high water prevails in the seasonal variability in sea level. The X-12-ARIMA approach makes it possible to estimate and distinguish fairly well the interannual variability of the June sea level maximum at this station. 

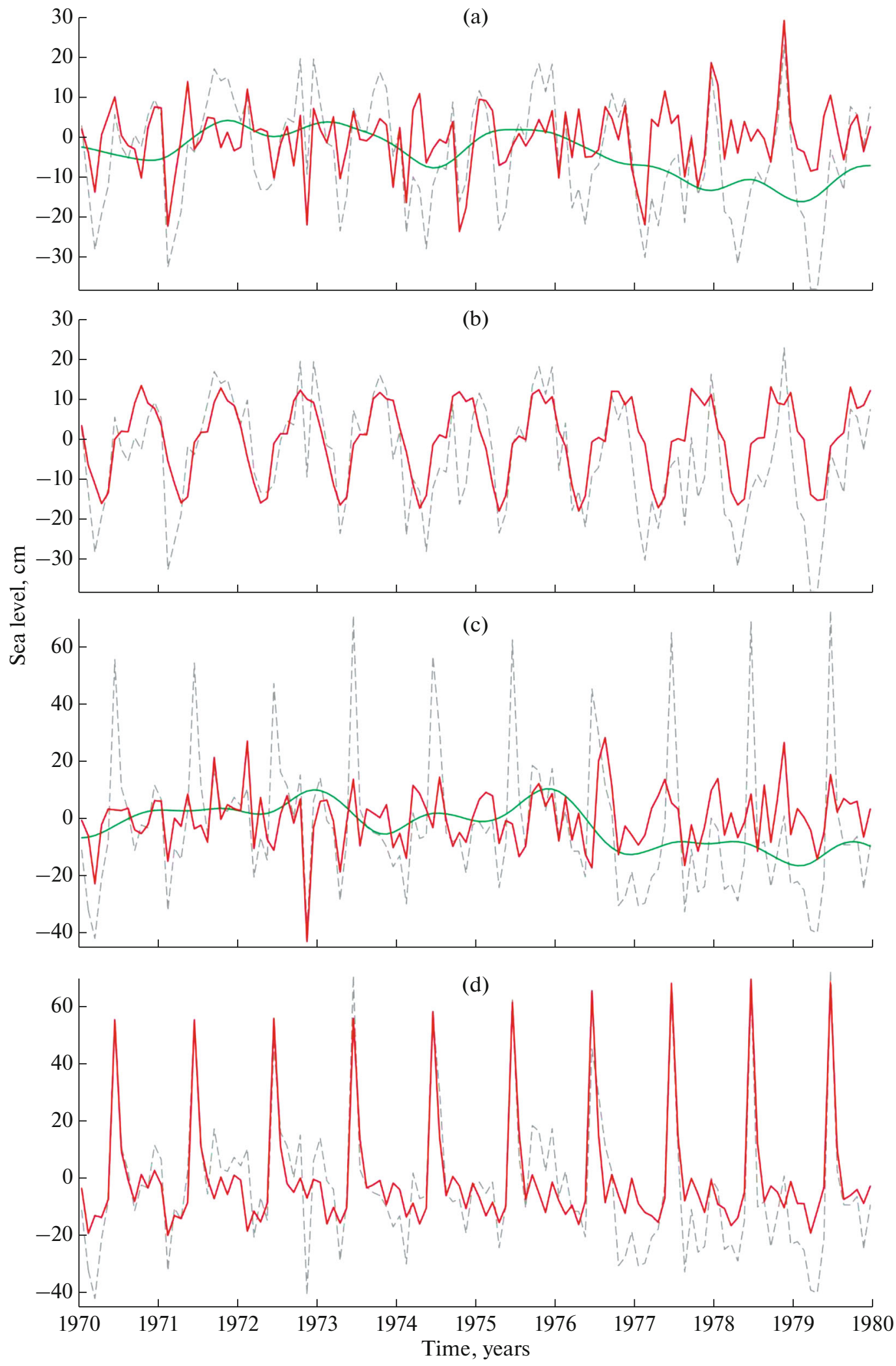

Fig. 6. Results of seasonal filtering of sea level oscillations at Amderma (a-b) and Sopochnaya Karga (c-d) stations. Gray dashed line shows initial sea level changes, green curve shows interannual sea level oscillations (trend component), and red curve shows irregular sea level oscillations (a) and (c) and seasonal sea level oscillations (b) and (d). 
The filtered series of seasonal sea level oscillations obtained using the X-12-ARIMA approach made it possible to estimate the interannual variability of seasonal sea level oscillations and their mean and extreme values. For each point, the annual values of the amplitude of seasonal oscillations $A_{\text {year }}$ were calculated as

$$
A_{\text {year }}=\left(L_{\max }-L_{\min }\right) / 2,
$$

where $L_{\max }$ and $L_{\min }$ are the maximum and minimum sea level values during one calendar year (12 months). At stations near estuarine zones, the amplitude of seasonal oscillations $A_{\text {year }}$ varies significantly from year to year. At the Sopochnaya Karga station, $A_{\text {year }}$ in some years may differ by two times, and at Ust-Kara station, even three times. Based on the $A_{\text {year }}$ values, the mean $A_{\text {mean }}$ and maximum $A_{\text {max }}$ amplitudes of seasonal sea level oscillations for each point were calculated. The spatial distribution of $A_{\text {mean }}$ values (Fig. 7a) is qualitatively similar to the distribution of the amplitudes of the annual harmonic $A_{s \mathrm{a}}$ (Fig. 2a). In the Barents and White seas, $A_{\text {mean }}$ varies from 9 to $13 \mathrm{~cm}$, with an anomaly at the Onega station in the mouth zone of the Onega River. In the western Kara Sea, $A_{\text {mean }}$ varies from 13 to $20 \mathrm{~cm}$, with maxima at the mouths of the Taz (Antipayuta, $45 \mathrm{~cm}$ ) and Yenisei (Sopochnaya Karga, $35 \mathrm{~cm}$ ) rivers. In the eastern Kara Sea and on the western coast of the Laptev Sea, there is a zone with minimum amplitudes of seasonal oscillations in sea level; $A_{\text {mean }}$ varies from 7 to $10 \mathrm{~cm}$. In estuaries of the Laptev Sea, the mean amplitude of seasonal oscillations increases sharply: up to $33 \mathrm{~cm}$ in Anabar, up to $68 \mathrm{~cm}$ in Ust-Olenek, and up to $56 \mathrm{~cm}$ at Sagyllakh-Ary station, near the Lena Delta. To the east, the amplitude of seasonal oscillations increases: up to $14 \mathrm{~cm}$ near the New Siberian Islands and up to $18 \mathrm{~cm}$ on the coasts of the East Siberian and Chukchi seas.

The maximum amplitudes of seasonal sea level oscillations $A_{\max }$ for the entire observation period for each station (Fig. 7b), on the whole, replicate the distribution of $A_{\text {mean }}$ values, exceeding them by $1.2-1.4$ times. The maximum values $A_{\max }$ were recorded in the estuaries of the Anabar (up to $43 \mathrm{~cm}$ ), $\mathrm{Ob}$, Yenisei (up to $50 \mathrm{~cm}$ ), Lena (up to $60 \mathrm{~cm}$ ), and Olenek (up to $76 \mathrm{~cm}$ ) rivers. For interannual changes $A_{\text {year }}$, negative trends are typical in the White Sea: $A_{\text {year }}$ decreases by $1-1.2 \%$ per year from $A_{\text {mean }}$ (Fig. 7c). In estuarine zones of the Kara Sea, negative trends prevail up to $-1.6 \%$ of $A_{\text {year }}$ per year at the Tadebya-Yakha station (the Gulf of Ob) and up to $-2.1 \%$ of $A_{\text {year }}$ per year at the Sopochnaya Karga station. Moreover, in the Gulf of $\mathrm{Ob}$, at other stations, a positive trend is observed: up to $1.8 \%$ of $A_{\text {year }}$ per year at the 80 let VLKSM and up to $3.6 \%$ of $A_{\text {year }}$ per year at the Cape Kamenny station. In the western Laptev Sea (on the coast of Severnaya Zemlya), negative trends prevail at a rate of -0.5 to $-0.7 \%$ of $A_{\text {year }}$ per year. In estuaries of Laptev Sea rivers, negative trends of variation in the mean amplitude are observed: up to $-4.6 \%$ per year at the mouth of the Anabar River, up to $-2.2 \%$ per year at the Naiba, and $-2.5 \%$ per year at the Sagyllah-Ary station in the Lena Delta. Moreover, at other observation points near the Lena Delta, positive trends of up to $0.3-0.4 \%$ of $A_{\text {year }}$ per year were noted (Fig. 7c).

\section{CLUSTER ANALYSIS}

The large number of stations used in the study made it possible to regionalize the water area of the Russian Arctic according to similar features of seasonal sea level oscillations. For this, a hierarchical cluster analysis of synchronous series of mean monthly sea level values from 1951 to 1990 was carried out (their locations are shown in Fig. 8b, and their names are given in Table 1), which makes it possible to group stations into larger clusters based on a certain distance measure. The Ward method [25] was used: minimization of the sum of squared deviations of any two clusters that can be formed at each step. As the distance measure, the Ward's method uses the increment of the sum of squared Euclidean distances between objects (stations) in a cluster and the centers of the cluster (centroids):

$$
d(r, s)=\sqrt{\frac{2 n_{r} n_{s}}{\left(n_{r}+n_{s}\right)}\left\|\bar{x}_{r}+\bar{x}_{s}\right\|_{2}},
$$

where \|\|$_{2}$ is the Euclidean distance, $\bar{x}_{r}$ and $\bar{x}_{s}$ are centroids $r$ and $s$, and $n_{r}$ and $n_{s}$ are the number of stations in clusters $r$ and $s$. At each step, clusters are combined for which the smallest increase in the total amount of distances is obtained. This method aims to combine closely spaced clusters.

As a result of the hierarchical cluster analysis, a dendrogram was constructed that shows the relatedness of seasonal oscillations at 33 stations (Fig. 8). When the critical (threshold) value of the Euclidean distance is less than 200, the stations were attributed to the same cluster. These clusters are highlighted in different colors in Fig. 8. Based on the cluster analysis results, four areas with high relatedness of seasonal sea level oscillations were distinguished: (1) Barents Sea, (2) Kara Sea, (3) Laptev Sea-East Siberian Sea, (4) Chukchi Sea. In general, these areas are related to the geographical location of the stations, but there are several interesting features. Thus, sea level oscillations at Yugorskiy Strait (no. 25 in Fig. 8) and Amderma (no. 26) stations in the Kara Sea are more closely related to sea level changes in the Barents Sea (Polyarnoye (no. 4) and Teriberka (no. 6) stations) than to those at the E.K. Fedorov (no. 23) and Ust-Kara (no. 27) stations located geographically closely to them. This is also confirmed by the estimates of the correlation $(R)$ of sea level oscillations: $R=0.90-0.91$ for the Yugorskiy Strait, Amderma, Polyarnoye, and Teriberka stations; for the Kara Sea cluster, with the western boundary at Dikson station (no. 36) and eastern boundary at the Andrey Island station (no. 52), $R=0.80-0.90$. The 

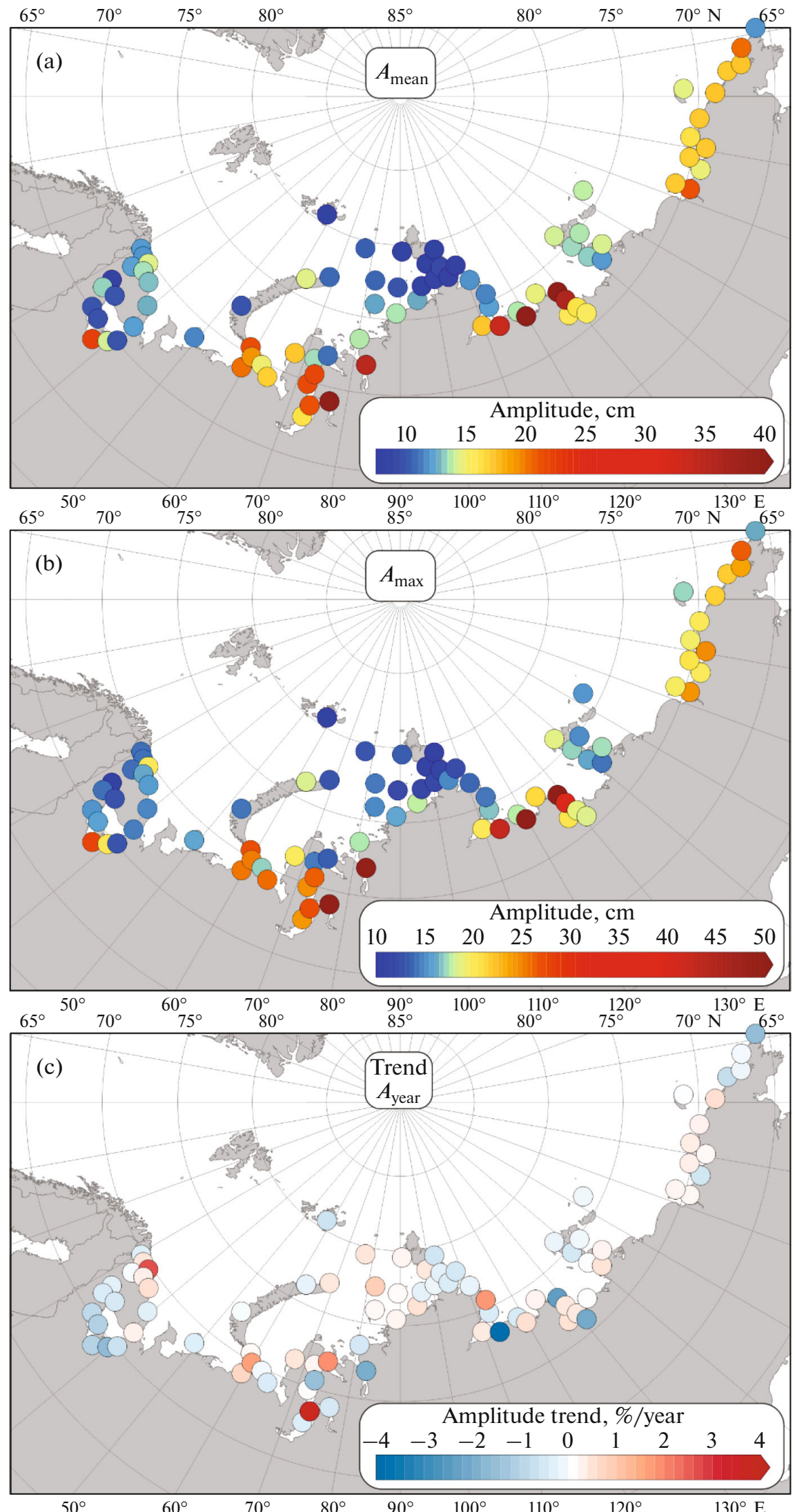

Fig. 7. Mean $A_{\text {mean }}$ (a) and maximum $A_{\max }$ (b) amplitudes of seasonal sea level oscillations in of Arctic seas, as well as rate of interannual variations in amplitude (values of linear trend as $\%$ of $A_{\text {mean }}$ per year) (c). 

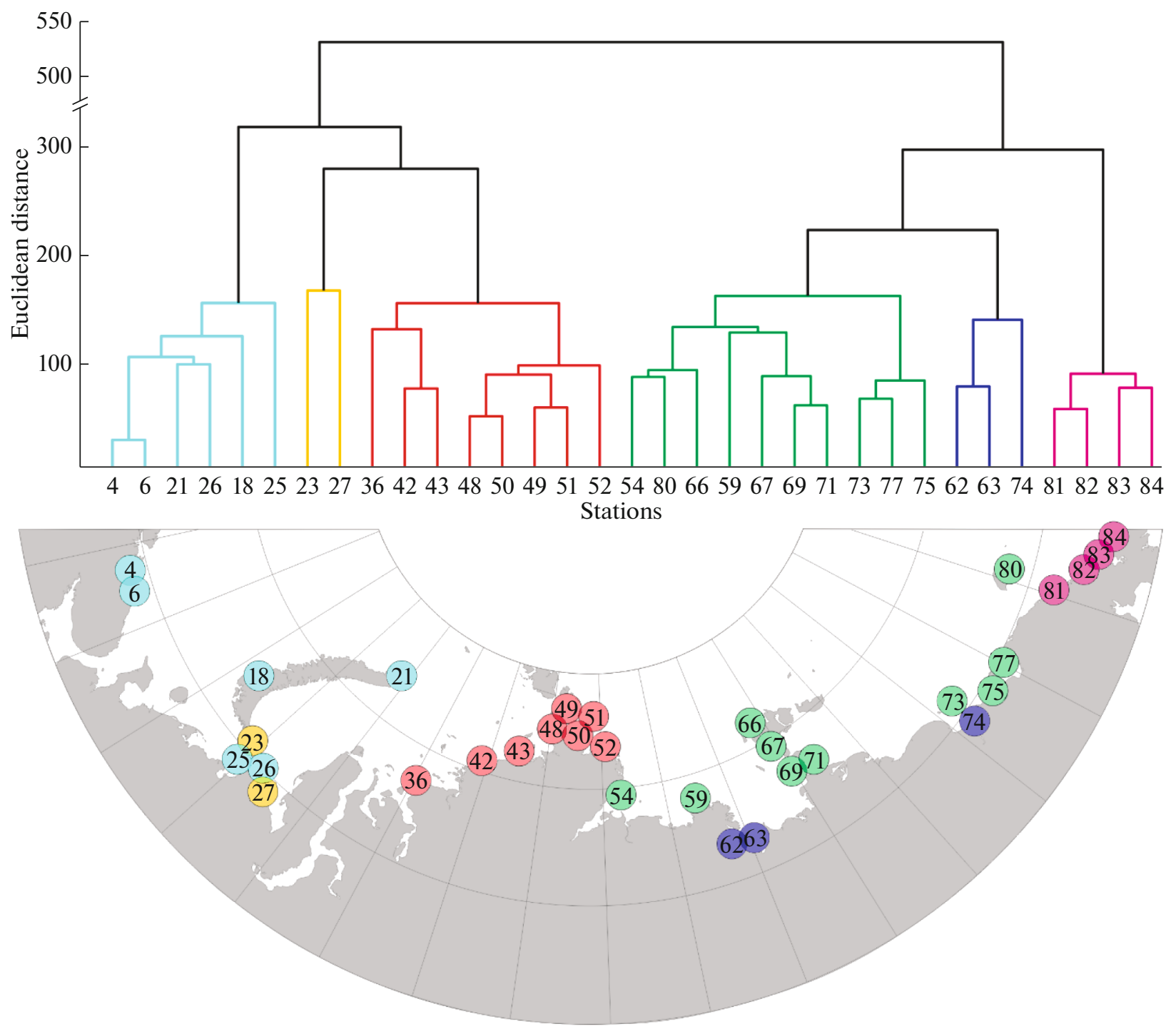

Fig. 8. Vertical dendrogram showing relatedness of seasonal sea level oscillations (a) at 33 stations in Arctic seas (b).

third region combines the Laptev and East Siberian seas. This area is also characterized by a high correlation. Moreover, we should especially mention the high relatedness $(R=0.91)$ between Preobrezhensky Island (no. 54) in the western Laptev Sea and Wrangel Island (no. 80) at the boundary of the East Siberian and Chukchi seas. The fourth region combines four stations in the Chukchi Sea (station nos. 81, 82, 83, 84). The stations in the estuarine areas of the seas are distinguished individually: Tiksi Bay (no. 62), Muostakh Island (no. 63), Ambarchik Bay (no. 74); their attribution to a separate cluster is probably due to the similar nature of the seasonal variability in sea level caused by high water.

\section{DISCUSSION AND CONCLUSIONS}

The study demonstrated the geographical features of the distribution of mean and extreme amplitudes of seasonal sea level oscillations in the Russian Arctic seas. An important issue that remained beyond its scope is an estimation of the contribution of various forcing factors to seasonal sea level oscillations in individual seas. It was shown in [20] that an increase in sea level in the Arctic seas in July-August is associated with a decrease in atmospheric pressure. Thermal oscillations in sea level have a maximum in the second half of August, when the seasonal solar radiation maximum is reached. The maximum sea level in September-October forms under the influence of increased storm activity, with an increase in the amount of atmospheric precipitation. In November-December, ice cover begins to form in the studied water areas, which reduces the effect of wind on the seasonal variability of sea level. The April minimum of the seasonal variability in sea level observed at almost all stations forms under the influence of several processes at once. During this period, there is a maximum atmospheric 
pressure [18], salinity, and ice cover distribution, while the sea water temperature approaches the freezing point and river runoff is close to zero.

According to [5], seasonal changes in atmospheric pressure are the main factor in seasonal sea level oscillations near the coasts of islands on the edge of the continental shelf. In the Kara, Laptev, and Chukchi seas, the effect of wind and atmospheric pressure is approximately the same, and on the coast of the East Siberian Sea, seasonal oscillations are largely controlled by the wind [5]. Numerical simulation results in [15] showed that thermohaline currents make the main contribution (up to 60-80\%) to sea level oscillations and the overall circulation of the Laptev Sea on seasonal and climatic scales. According to [7], seasonal oscillations in sea level in the Arctic are 50-80\% determined by the wind effect. Meanwhile, drift ice has hardly any effect on the spatial features of seasonal sea level oscillations. However, the stationary ice cover, including fast ice, screens the effect of shear wind stresses, thereby reducing its influence in the coastal parts of water areas in winter-spring.

An increase in river runoff during the flood period sharply disturbs the harmonious nature of the seasonal variability in sea level and generates the local maximum in June. This feature is most pronounced in the estuarine areas of seas, where the mean sea level can sharply increase by $30-50 \mathrm{~cm}$. As a result, the amplitude of semiannual oscillations increases and seasonal overtones appear in the spectra (semiannual $S$ sa, third-annual $S t a$, and quarter-annual $S q a)$. In the Chukchi Sea, the shape of the seasonal variability curve approaches a sinusoid, caused by the absence of runoff from large rivers into the sea.

As shown in Section 3, the astronomical tidal component $S$ a has amplitudes in the Arctic up to $0.2 \mathrm{~cm}$ and is only about $2-3 \%$ of the amplitude of the annual component of sea level oscillations. The amplitude of the semiannual static tide $S$ sa is significantly larger; at the latitude of the seas under consideration, up to $1.3 \mathrm{~cm}$. Thus, for some points of the Arctic coast, e.g., for stations in the Chukchi (Cape Vankarem, Cape Netten, Ratmanov Island), Barents (Pechenga, Polyarnoye, Teriberka, etc.), and White (Kandalaksha, Kem-port, Solovki, etc.) seas, the contribution of the astronomical tidal component becomes significant and has amplitudes close to those of the total component $S$ sa (see Table 1).

Filtered series obtained using the X-12-ARIMA approach made it possible to estimate the extreme values of seasonal sea level oscillations. The mean amplitude of seasonal sea level oscillations $A_{\text {mean }}$ varies from $10 \mathrm{~cm}$ in the White Sea to $16 \mathrm{~cm}$ on the coasts of the East Siberian and Chukchi seas. The maximum values of the amplitude of seasonal oscillations in sea level $A_{\max }$ for the entire observation period for each station as a whole replicate the distribution $A_{\text {mean }}$, exceeding them by $1.2-1.4$ times. The maximum values $A_{\max }$ are reached in estuarine areas: up to $50 \mathrm{~cm}$ in Yenisei Gulf and the Gulf of $\mathrm{Ob}$, up to $60 \mathrm{~cm}$ near the mouth of the Lena River, and up to $75 \mathrm{~cm}$ at the mouth of the Olenek River. Those. during the year, the range of variations in the mean sea level can reach $100 \mathrm{~cm}$ in the Yenisei Gulf and up to $150 \mathrm{~cm}$ at the mouth of the Olenok River Thus, the amplitudes of seasonal oscillations at the estuaries of Siberian rivers are close to the extreme values of seasonal oscillations observed at the estuaries of the largest rivers flowing into the World Ocean: e.g., the Ganges (up to $100 \mathrm{~cm}$ ) and St. Lawrence (up to $50 \mathrm{~cm}$ ) [21, 22].

The next step in development of this study will be to assess the contribution of different forcing factors to the seasonal sea level oscillations in the Arctic seas.

\section{FUNDING}

The work was carried out within the state task of IO RAS, topic no. 0128-2021-0004 and was supported by the Russian Science Foundation, grant no. 20-77-00099 and the Russian Foundation for Basic Research, project no. 18-05-60250.

\section{OPEN ACCESS}

This article is licensed under a Creative Commons Attribution 4.0 International License, which permits use, sharing, adaptation, distribution and reproduction in any medium or format, as long as you give appropriate credit to the original author(s) and the source, provide a link to the Creative Commons license, and indicate if changes were made. The images or other third party material in this article are included in the article's Creative Commons license, unless indicated otherwise in a credit line to the material. If material is not included in the article's Creative Commons license and your intended use is not permitted by statutory regulation or exceeds the permitted use, you will need to obtain permission directly from the copyright holder. To view a copy of this license, visit http://creativecommons.org/licenses/by/4.0/.

\section{REFERENCES}

1. I. M. Ashik, A. S. Makarov, and D. Yu. Bol'shiyanov, "Development of coasts of the Russian Arctic related with the sea level fluctuations," Meteospektr, No. 2, 23-27 (2010).

2. V. N. Vorob'ev, S. Yu. Kochanov, and N. P. Smirnov, Seasonal and Long-Term Fluctuations of the Sea Level of the Arctic Ocean (Russian State Hydrometeorological Univ., St. Petersburg, 2000) [in Russian].

3. E. N. Dvorkin, Yu. V. Zakharov, and N. V. Mustafin, "The reasons of seasonal and long-term variability of the level of the Laptev and East Siberian seas," Tr. Arkt. Antarkt. Nauchno-Issled. Inst. 349, 60-68 (1978).

4. E. N. Dvorkin, Yu. V. Zakharov, and N. V. Mustafin, "Reasons of seasonal and long-term variability of the Chukchi Sea level," Tr. Arkt. Antarkt. Nauchno-Issled. Inst. 349, 69-75 (1978).

5. E. N. Dvorkin, Yu. V. Zakharov, and N. V. Mustafin, "Seasonal and long-term fluctuations of the level of the 
Arctic seas," Probl. Arkt. Antarkt., No. 60, 10-17 (1985).

6. I. P. Medvedev, "Interannual variability of seasonal level fluctuations on the Russian coast of the Baltic Sea," Okeanol. Issled. 46 (3), 35-50 (2018). https://doi.org/10.29006/1564-2291.JOR-2018.46(3).3

7. A. Yu. Proshutinskii, Level Fluctuations of the Arctic Ocean (Gidrometeoizdat, St. Petersburg, 1993) [in Russian].

8. J. A. Church, P. U. Clark, A. Cazenave, et al., "Sea level change," in Climate Change 2013: The Physical Science Basis. Contribution of Working Group I to the Fifth Assessment Report of the Intergovernmental Panel on Climate Change, Ed. by T. F. Stocker, , (Cambridge University Press, Cambridge, 2013).

9. E. B. Dagum, The X-11-ARIMA Seasonal Adjustment Method (Statistics Canada, Ottawa, 1980).

10. S. Dangendorf, T. Wahl, C. Mudersbach, and J. Jensen, "The seasonal mean sea level cycle in the southeastern North Sea," J. Coastal Res. 65 (2), 1915-1920 (2013).

11. D. F. Findley, B. C. Monsell, W. R. Bell, et al., "New capabilities and methods of the X-12-ARIMA seasonal-adjustment program,” J. Bus. Econ. Stat. 16 (2), 127-152 (1998).

12. A. E. Gill and P. P. Niller, "The theory of the seasonal variability in the ocean," Deep-Sea Res. Oceanogr. Abstr. 20 (2), 141-177 (1973).

https://doi.org/10.1016/0011-7471(73)90049-1

13. M. Oppenheimer, B. C. Glavovic, and J. Hinkel, "Sea level rise and implications for low-lying islands, coasts and communities," in IPCC Special Report on the Ocean and Cryosphere in a Changing Climate, Ed. by H.-O. Pörtner, D. C. Roberts, V. Masson-Delmotte, et al. (Intergovernmental Panel on Climate Change, Geneva, 2019). https://www.ipcc.ch/site/assets/uploads/sites/3/2019/ 12/SROCC_FullReport_FINAL.pdf. Cited February 29, 2020.

14. V. K. Pavlov, "Seasonal and long-term sea level variability in the marginal seas of the Arctic Ocean," Polar Res. 20 (2), 153-160 (2001).

15. V. K. Pavlov and P. V. Pavlov, "Features of seasonal and interannual variability of the level regime and water cir- culation in the Laptev Sea," in Land-Ocean Systems in the Siberian Arctic: Dynamics and History, Ed. by H. Kassens, (Springer-Verlag, Berlin, 1999), pp. 3-16.

16. W. R. Peltier, "Global glacial isostasy and the surface of the Ice-Age Earth: the ICE-5G(VM2) model and GRACE,” Annu. Rev. Earth Planet. Sci. 32, 111-149 (2004). https://doi.org/10.1146/annurev.earth.32.082503.144359

17. S. Pezzulli, D. B. Stephenson, and A. Hannachi, "The variability of seasonality,” J. Clim. 18 (1), 71-88 (2005).

18. I. V. Polyakov, A. Y. Proshutinsky, and M. A. Johnson, "Seasonal cycles in two regimes of Arctic climate," J. Geophys. Res.: Oceans 104 (11), 25761-25788 (1999).

19. A. Proshutinsky, I. M. Ashik, E. N. Dvorkin, et al., "Secular sea level change in the Russian sector of the Arctic Ocean,” J. Geophys. Res.: Oceans 109, C03042 (2004). https://doi.org/10.1029/2003JC002007

20. A. Proshutinsky, I. Ashik, S. Häkkinen, et al., "Sea level variability in the Arctic Ocean from AOMIP models,” J. Geophys. Res.: Oceans 112, C04S08 (2007). https://doi.org/10.1029/2006JC003916

21. D. Pugh and P. Woodworth, Sea-Level Science: Understanding Tides, Surges, Tsunamis and Mean Sea-Level Changes (Cambridge University Press, Cambridge, 2014).

22. M. N. Tsimplis and P. L. Woodworth, "The global distribution of the seasonal sea level cycle calculated from coastal tide gauge data," J. Geophys. Res.: Oceans 99, 16031-16039 (1994).

https://doi.org/10.1029/94JC0 1115.

23. S. V. Vinogradov and R. M. Ponte, "Annual cycle in coastal sea level from tide gauges and altimetry," J. Geophys. Res.: Oceans 115, C04021 (2010). https://doi.org/10.1029/2009JC005767

24. D. L. Volkov and M. I. Pujol, "Quality assessment of a satellite altimetry data product in the Nordic, Barents, and Kara seas,” J. Geophys. Res.: Oceans 117, C03025 (2012). https://doi.org/10.1029/2011JC007557

25. J. H. Ward Jr., "Hierarchical grouping to optimize an objective function,” J. Am. Stat. Assoc. 58, 236-244 (1963). 